\title{
AN APPRAISAL OF TRANSPORTATION FACILITIES EFFECTS ON AGRICULTURAL DEVELOPMENT IN MORO LOCAL GOVERNMENT AREA, KWARA STATE, NIGERIA

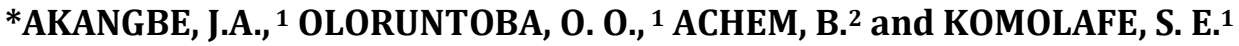

\author{
http://dx.doi.org/10.4314/ejesm.v6i2.10
}

Received 4th April 2012; accepted 27th February 2013

\begin{abstract}
This paper was designed to assess the state and effects of transportation facilities on agricultural development of rural farmers in Moro Local Government Areas of Kwara State. The study made use of structured interview schedules to collect data from 150 farmers by means of four-stage random sampling technique. Analytical tools used include Pearson Product moment correlation and Kruskalwallis ranking. Findings show that mode of transportation in the study area is mostly through headporterage and to a short distance, limiting number of produce that are hulled to the market with little income realized. Motor-cycles are used by some farmers while pick-up vans and small trucks are equally used with huge amount of transport money during haulage. Perishable crops like tomatoes, okra, pepper and yams get damaged in the course of transporting as a result of excessive heat and poor winding and bending roads resulting in loss of quality and reduction in farmers' income; eventually discouraging farmers in expanding his farm size the next growing season. Furthermore, the study found that about $60 \%$ of the farmers sell produce at farm gates as a result of high cost of transportation. While constraints in using transportation facilities such as road seasonality, cost of transportation and number of vehicles plying the road with mean of 589.66, 536.46 and 501.50 ranked first, second and third respectively. About $64.7 \%$ agreed that these constraints affect their accessibility to agricultural facilities. This has a long devastating effect on agricultural development of the study area. To improve transportation facilities in the area, there is need for rural infrastructural development and need to revive the rail-road system of transportation in rural areas.
\end{abstract}

Key words: Assessment, Transportation facilities, Agricultural development and rural farmers.

\section{Introduction}

Agriculture has been identified as the primary and biggest source of income in rural communities and provides employment to approximately 70 percent of its population (Pal, 2005). Hill (2008) opined that a significant proportion of agricultural task involve moving equipment and materials from one place to another which involve a wide variety of types and sizes of loads to be moved over different distances and types of terrain.

Transport is indispensable to economic development especially in a developing country like Nigeria. This is because transport is essential to execution of daily economic and social activities in any given area. Girvan (2007) stated that transportation is a necessary precursor to the development of agricultural productivity and has a unique role and relationship with agriculture development because of the characteristics of agricultural production, commodities and markets.
Crosssley et al. (2009) examined that transport operations are a basic component of agricultural input and produce supply chains and that transport can be the decisive factor for the success of a farm or business activity, or else the one constraint that makes costs prohibitive or renders a project economically non-viable. Njenga and Mbara (2005) claimed that transportation has the ability to intensify inequalities and deepen poverty if its negative externalities are not appropriately managed and thus transport by itself cannot have a decisive impact on poverty. Crossley et al (2009) recognized transport has a major component of the operation cost in the food chain and it's becoming a barrier for small-scale producers and for the development of efficient, lucrative agribusinesses. World Bank (1999) indicated that the availability of transport provides the poor with better physical access to markets and other social amenities such as education and health services. World Bank (ref)

${ }^{1}$ Department of Agricultural Extension and Rural

Development University of Ilorin, Ilorin, Nigeria.

${ }^{2}$ National Center for agricultural mechanisation,

Ilorin. Nigeria

*Corresponding author: jonesajangbe@gmail.com 
further stated that there is ample evidence that the availability of transport enhances agricultural productivity by addressing the spatial dislocation and any unacceptable distributional consequences associated with lack of adequate means of transport particularly for the rural poor.

Jacoby (2000) reported that road has particular important form of rural infrastructure providing cheap access to markets for agricultural output, thus improving access to rural transportation can stimulate economic development (Friedman, 2004) thereby increasing production capabilities of the rural farmers. Howe (2001) affirms that a better understanding of rural transport demands and constraints requires a more thorough analysis of the needs of individual households. Njenga and Mbara (2005) identified transport as a key ingredient in the development of rural areas which provides people with access to various goods and services. They further stressed that human development hinges on efficient transport which enables access to markets and service, information, opportunities and, networks. Davis (2000) indicated that transport constraints on rural livelihoods are not simply a result of poor road condition, but are a culmination of inadequate infrastructure, poor public transport provision and exorbitant tariffs imposed by private transporters whose services are infrequent, and further impede the ability of the rural to generate a sustainable livelihood. Hine and Ellis (2001), stated that the pattern of agricultural marketing is strongly influenced by the nature of transport services and that if transport services are infrequent, of poor quality or expensive then farmers will be at a disadvantage when they attempt to sell their crops. They further argued that the main causes of high transport cost identified by Hine and Ellis (2001) appear to be a combination of high input costs, low utilization and poor maintenance. Seasonally impassable roads or slow and infrequent transport services, coupled with poor storage, can lead to losses as certain crops (e.g. milk, fresh vegetables, tea) deteriorate quickly over time. If the journey to market is made over rough roads then other crops (e.g. bananas, mangoes) may also suffer losses from bruising; this will also result in lower prices to the farmer.

Heather and Gordon (2001) reported that the benefits from rural infrastructure development activities are inter-related and are generally targeted at increasing access as a means of improving rural living standards and incomes. Road and other transport improvements thus provide support to a range of rural development activities, such as:

- providing improved access to areas outside the village, so that agricultural surplus can reach collection centres and markets more rapidly;

- reducing the time burden on family members, particularly (in some cultures) the younger and female members of the family;

- reducing damage to perishable crops during transport;

- reducing operating costs for vehicle users; and

- providing greater opportunities for social and educational journeys and providing more direct and cost-efficient access to public services, such as schools and health facilities.

The general objective of this study was to assess transportation facilities on agricultural development of rural farmers in Moro local government Area of Kwara State. The specific objectives of the study are to:

1. Identify the socio-economic characteristics of the farmers in the study area.

2. Assess the modes of transportation in the study area.

3. Examine financial implication of transporting their produce in the study area.

4. Examine transport constraints faced by the farmers in the study area.

5. Investigate the effect of transportation facilities of on the agricultural development of the people.

\section{Methodology \\ Study Area}

The study was conducted in Kwara State, Nigeria. Kwara State is located between latitudes $7^{\circ} 45^{\prime} \mathrm{N}$ and $9^{\circ} 30^{\prime} \mathrm{N}$ and longitudes $2^{\circ} 30^{\prime} \mathrm{E}$ and $6^{\circ} 25^{\prime} \mathrm{E}$ (KWADP, 1996). Kwara State has 16 Local Governments Areas (LGA's) where Moro local government was selected by simple random selection as the study area. Moro local government is made up of various ethnic groups which include Yoruba, Nupes, Fulanis, and Hausa speaking people. The people of this local government are predominantly farmers because the area is endowed with a wide expense of arable and rich 
fertile soil. The food crop grown in the area are; cassava, yam, maize, guinea corn, Okro, groundnut, pepper and vegetables. Rearing of livestock such as sheep, goats, cattle and poultry keeping are made possible because of the type of the type of vegetation.

Five (5) districts were selected by cluster sampling where two villages were selected randomly from each district to give a total of ten (10) villages. From Lanwa district, the villages were Ekejo and Oke-Osin; Malete district, the villages were Adegimi and Jekunu, Ejidongari district, villages were Iyana-mama and Gboro, Oloru district, villages were Adio and Yeregi and Ipaye district, villages were Megida and Oloworu. Fifteen (15) farmers were selected through snowballing method from each of the ten (10) villages. This gave a total sample size of one fifty (150) farmers.

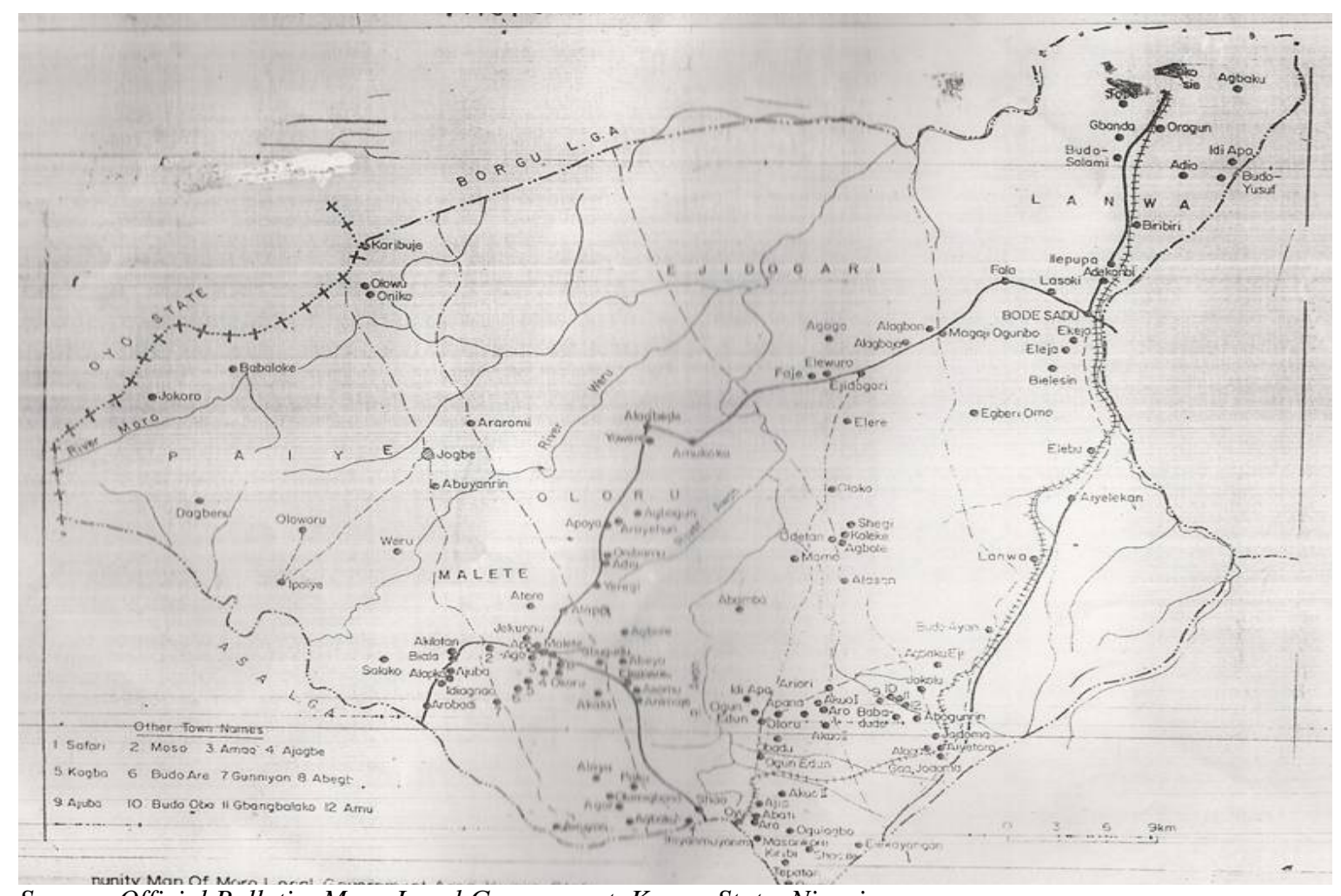

Source: Official Bulletin, Moro Local Government, Kwara State, Nigeria

Figure 1 Map of Study Area

\section{Sampling}

Five (5) districts were selected by cluster sampling where two villages were selected randomly from each district to give a total of ten (10) villages. From Lanwa district, the villages were Ekejo and Oke-Osin; Malete district, the villages were Adegimi and Jekunu, Ejidongari district, villages were Iyana-mama and Gboro, Oloru district, villages were Adio and Yeregi and Ipaye district, villages were Megida and Oloworu. Fifteen (15) farmers were selected through snowballing method from each of the ten (10) villages.
This gave a total sample size of one fifty (150) farmers.

The main instrument used to collect primary data for this study was structured interview schedule which comprised five sections. Each section examined specific objectives with a view to seeking information for the purpose of this research.

Section A: Socio-economics information of farmers in the study area.

Section B: Types of transportation facilities in the study area. 
Section C: constraints faced in the used of transportation facilities.

Section D: Effect of transportation facilities on agricultural development of the people.

Transportation mode was the only dependent variable measure used to determine the type of transport facilities available to the respondents in the study area.

\section{Data Analyses}

Descriptive statistics technique such as percentages, frequencies and means was used to highlight the socio-economic characteristics of the farmers in the study area. The SPSS package was used to analyse data employing univariate and multivariate methods. The multivariate analysis involved the use of Pearson product moment correlation (ppm). Descriptive statistical technique such as percentages, frequencies, means and Kruskal-Wallis one-way Analysis of variance (ANOVA) by ranks was used for objective 2, 4, and 5.

\section{Result and Discussion}

Data analysis presented in table 1 revealed that majority $89.3 \%$ of the respondents were males while $10.7 \%$ were female who are responsible for marking and processing of produce. Majority of the respondents fall within the age of 26-46 years and the mean age being 44 years which are classified as active and middle age according to Jibowo, (2000).

Deductions from table 1 revealed that majority of the respondents $97.3 \%$ were married. This suggests that they may have access to family labour. Also, this conforms to the findings of Siyanbola (1995) and Jibowo (2000) that majority of the adult population of any society consists of married people.

Most of the farmers $36.7 \%$ did not receive any formal education. The predominance of those without any formal education has to do with the general lack of quality infrastructure and personnel. The problem is further compounded when the educational background of their predecessors are considered. Transportation of produce may have very little need for sophisticated level of education.

Farming as a full-time occupation accounted for $92.7 \%$ indicating that majority of the farmers depend solely on agriculture for their livelihood. This implies that agrarian societies are involved in the production, processing and marketing of agricultural produce.

About a quarter of the farmers $46 \%$ had a household size of $4-10$ people while $2.7 \%$ had household above 24 people with mean household size of 12 people. This finding suggests that majority of the farmers have a relatively small household size and as a result they are disadvantaged when it comes to family labour.

Analysis presented in table 1 shows that slightly above half $54 \%$ of the respondents fall in the modal farm size of 6-16ha of farmland. While only $0.7 \%$ of the farmers had up to $20 \mathrm{ha}$ of farmland for agricultural production. The mean farm size being $12 \mathrm{ha}$, this finding shows that the farmers have access to land for agricultural production. In Kwara state, Moro LGA is one of the few areas with the largest land areas, although this does not translate to fertility of the land for agricultural production.

Results in table 1 showed modal experience of 17-27 years which account for above one-fifth $37.3 \%$ of the farmers with mean experience of 23 years while $3.3 \%$ of the farmers had less than five years of experience. This implies that the farmers have wealth of experience in farming. The better the number of farming the more experience gained both in farming and transportation of produce.

Above half of the respondents $76 \%$ produce for the market and household consumption while $12 \%$ produce at subsistence and commercial level respectively. This implies there is no division between quality prepared for household consumption for and prepared for market which in most cases, quantity eaten by household surpasses what is taken to the market for sale hence implication on their income.

About a quarter of the farmers $36.7 \%$ earn between N10, 000-205,999 per annum while $10 \%$ earn N402, 000-N597, 999 per annum.

Table 2 shows that majority $58.65 \%$ of the respondents sell their produce at farm gate while $41.35 \%$ sell at retail. This is because they believe it will take a long time to sell their produce due to limited vehicle traffic that leads to their villages. They also see their produce as security against cash crunch as they can quickly dispose off their wares without hampering their farm activities.

Table 2 reveals that only $26 \%$ of the respondents spend about N15,000 while a few $2.6 \%$ spend $\mathrm{N} 135,000$ to transport their produce 
from farm to market. This implies that majority spend between $10-20 \%$ of their annual income on transport.

Majority of the respondents $70 \%$ believe that cost of transporting farm produce is high. In the course of survey; farmers were asked reasons for this situation. The reasons includes amongst others high input cost with $64.0 \%$ monopolistic practices with $70.0 \%$ ascending to this. While road seasonality topped the chart with $71.3 \%$ confirming that the state of the road is a good excuse for the high cost of transportation. This confirms with the findings of Hine and Ellis (2001) that transport operating costs are higher on rough roads than on good quality bitumen roads. Deduction from table 2 shows that $47.0 \%$ indicated that distance and road seasonality are a major constraint in the use of transportation facilities. This may be due to poor condition of the road that jacked up transport fares during raining seasons. About $44.7 \%$ indicated them as a minor constraint.

Table 2 shows that $58 \%$ and $37 \%$ of respondents indicated constraints to be very severe and severe respectively while few 5\% indicated that contraints mentioned are not severe. Table 2 shows that distance to market $32 \%$ sell their produce near-by at cheaper rate while for road network $31 \%$ sell to middle men while road seasonality cause $20 \%$ to resort to head loading and use of canoe during the raining season when rivers overflows their banks hence impeding the few vehicular activities. This further increase the amount they spend on transportation as cost of transportation is high when $26.7 \%$ resort to selling part of their produce locally. All these have effect/implication on their income. Majority of the respondents $78.6 \%$ do not have access to agricultural extension agents, agricultural credit, agricultural produce market, Agro-chemical, Improved seed and tractor usage. This could be implication of the distance of their locality and road situation which is bad. This scenario could be denying them the opportunity of getting to know about new innovation which could only happen with good communication with the outsider world.

About $35.9 \%$ and $32.6 \%$ of respondent show that transportation facilities serve as barrier to agricultural development. This is because their locality is far away from the urban centre, the roads are bad hence high transport to get to the urban centre (finance house) leading to being forgotten and left for the worse. To access loan they believe you must be available physically which in most cases is impossible due to aforementioned factors. This finding agrees with Crossley et al (2009) that transport could be the decisive factor for the success of a farm or else the one constraint that make cost prohibitive and becoming a barrier for small-scale producers. Respondents' opinion on transport facilities and agric. Development in table 2 shows that $66.1 \%$ strongly agreed while $33.9 \%$ just agreed. This tally with Njenga and Priyanthi (2007), as they see transport as being a physical asset and also an essential link in the utilization of other assets and having the ability to improve access to product markets that could stimulate surplus farm production.

Table 3 shows that Pick-up has the highest mean score with head porterage following closely. This conforms to Ninnin (1997) findings that usually pick-up or small trucks are used in rural transport while heavy tractor or semi-trailer are used in inter-urban transport. Road seasonality and cost of transportation ranked first and second respectively in constraints faced in using transportation facilities while farming input and agricultural product market ranked first and second respectively in the effect of agricultural facilities on agricultural development. In Giwa Local Government Area, over 50\% the roads are usually out of use during the raining season (Foin, 2007).

Result of finding in table 4 shows that none of the relationship between socio-economic variables and transport mode of the farmers was significant at level $1 \%$ and $5 \%$ level of significant. This could be due to the fact that transportation choice is beyond their control as a result of the state of their roads. They believe that even if you have vehicle without payment for transport service, the state of roads has limited the type of vehicles that can come into their farms to transport their goods.

In Ejidongari district, nature of road network and type of commodity were the most prevalent problems in the district with a mean of 96.50 and 102 respectively. This is so because the roads here are badly connected such that it becomes farm so frustrating locating or transporter thus leading to high transport cost. The farmers in these districts are into the production of variety of agricultural 
produce, such as tomatoes, groundnuts, guinea corn, pepper, Okro, even soya beans. They said transporting vegetables such as tomatoes on their winding and bending roads causes damage to their produce leading to a loss of quality of their produce.

In Oloru district, cost of transportation and distance of farm to market were reported as their problem to efficient transportation in the district. Each had means of 95.48 and 81.78 respectively. Responded stated that the cost of transporting a pick-up load of yam from farm ranges between N1400-N1800, while for cassava, it ranges between N2200-N2600 per pick-up load, which they see as been rather high. Distance to market becomes a problem as most of them sell their produce at Alapa market where the yam tubers are bought by middlemen for onward transportation and sales in Abuja, federal Capital Territory, Nigeria.

In Megida district, Road seasonality (113.48) and number of vehicle plying their roads (84.12) were of great concern to them because they see these as a hindrance to efficient transportation of their produce. Given that, were situation reversed, they will have better opportunity to bargain with public transporter and it will become the higher bargaining power the higher the discount. But where there is no access to road most especially during the rains when they are cut-off from civilization due to the overflowing of the river in their community making the only bridge linking their community impassable. Thus at those times, the few vehicles that come around charge exorbitantly as stating road diversion as their reason for charging so high. Also, at such time, they result to the use of inter-modal transportation. Here, they board vehicle to the river, then board canoes to carry their produce across the river and another vehicle to transport their produce to the market.

In Lanwa district, distance of farm to market and nature of road network were the most prevalent problem in the district as revealed in table 5 with means 79.37 and 75.97. This is due to the declining soil fertility within the community, forcing farmers to go farther into the bush in search of virgin land which is believed to be fertile. Though, there is fairly bountiful harvest but when it comes to transporting their produce, it becomes difficult and stressful to get vehicles that will transport their produce. Even when they finally get one, they are bound to the fares they charge or run the risk of leaving their produce on the farm where it could be stolen or eaten by wild animals.

Therefore, there is a significant relationship between the constraints to efficient transportation across the districts in the study area.

\section{Conclusion}

This study shows that transportation facilities in the study area are in poor state. This is obvious having a negative implication on agricultural development.

\section{Recommendation}

Based on the findings, the paper recommends the need for infrastructural development advocacy and to revive the rail system of transportation of rural farmers. Also, there is need for research and dissemination of information in order to improve understanding on rural transport needs and travels in the rural areas to support agricultural development.

\section{References}

Crossley, P., Chamen, T and Kienzle, J. (2009), Rural Transport and Traction Enterprises for Improved Livelihoods, diversification booklet 10 . Davis, A. S. C. (2000), The application of transport and sustainable rural livelihoods in Zambia: a case study, Rural Transport Knowledge Base 1 Rural Travel and Transport Program, 5 (3b), 1-15.

Foin, D. N. (2007), The impact of Road Network on the Distribution of Social Amenities in Giwa Local Government. The Information Manager 7. Friedman, P. (2004), Transportation Needs in Rural Communities, Rural Assistance Center, 2 (1), Pp. 1-9.

Girvan, N. (2007), Towards a single development vision and the Role of the single economy. Working Paper prepared In Collaboration with the CARICOM Secretariat and the Special Task Force on the Single Economy

Hine, J. L. and Ellis, S. D. (2001), Agricultural marketing and access to transport services, Rural Transport Knowledge Base 1 Rural Travel and Transport Program, 4 (3a), 1-11.

Holy, H. (2008), Unlocking the Potentials of resources poor communities in Innovative 
business partnerships, Kenya Network for Dissemination of Agricultural Technologies (KENDAT) Pp. 1-44.

Howe, J. (2001), Village level transport, Rural Transport Knowledge Base 1. (1a), Pp 1-15.

Kindness, H., and Gordon, A. (2001), National Resource Institute, Agricultural Marketing in Developing (policy series 12): The Role of NGOs and CBOs.

Ninnin, B. (1997), Transport for Development A Madagascar. French Cooperation. Ministry and Malagasy Public Works Ministry, INRETS.
Varunika, P. (2005), UTTAR/ANCHAL: Constraints in agriculture practices and its future prospects, central hemalayan environment association, 1(5), Pp 1-5.

Peter, N., and Mbara, T. (2005), Repositioning the rural transport and development agenda:

Challenge for eastern and southern Africa, International Forum for Rural Transport and Development.

World Bank (1999). Rural Travel and Transport Project. Washington D.C: World Bank

Table 1 Distribution of respondents according to their socio-economic characteristics

\begin{tabular}{|c|c|c|c|}
\hline \multirow[t]{4}{*}{1} & & Frequency & Percentages \\
\hline & Gender & & \\
\hline & Male & 134 & 89.3 \\
\hline & Female & 16 & 10.7 \\
\hline \multirow[t]{5}{*}{2} & Age & & \\
\hline & $<25$ & 10 & 6.7 \\
\hline & $26-46$ & 85 & 56.6 \\
\hline & $47-67$ & 54 & 36.0 \\
\hline & $>68$ & 1 & 0.7 \\
\hline \multirow[t]{3}{*}{3} & Marital Status & & \\
\hline & Married & 146 & 97.3 \\
\hline & Single & 4 & 2.7 \\
\hline \multirow[t]{6}{*}{4} & Educational Status & & \\
\hline & No formal & 55 & 36.7 \\
\hline & Quranic & 21 & 14.0 \\
\hline & Primary & 38 & 25.3 \\
\hline & Secondary & 31 & 20.7 \\
\hline & Tertiary & 5 & 3.3 \\
\hline \multirow[t]{3}{*}{5} & Farming Status & & \\
\hline & Full-time & 139 & 92.7 \\
\hline & Part-time & 11 & 7.3 \\
\hline \multirow[t]{6}{*}{6} & Household size (people) & & \\
\hline & $<3$ & 1 & 0.7 \\
\hline & $4-10$ & 69 & 46.0 \\
\hline & $11-16$ & 53 & 35.3 \\
\hline & $17-23$ & 23 & 15.3 \\
\hline & $>50$ & 4 & 2.7 \\
\hline \multirow[t]{7}{*}{7} & Farming experience (year) & & \\
\hline & $<3$ & 5 & 3.5 \\
\hline & $6-16$ & 48 & 32.1 \\
\hline & $17-27$ & 56 & 37.3 \\
\hline & $28-38$ & 20 & 13.3 \\
\hline & $39-49$ & 14 & 9.3 \\
\hline & $>50$ & 7 & 4.7 \\
\hline \multirow[t]{5}{*}{8} & Farm size (ha) & & \\
\hline & $<5$ & 61 & 40.7 \\
\hline & $6-16$ & 81 & 54.0 \\
\hline & $17-27$ & 7 & 4.6 \\
\hline & $>20$ & 1 & 0.7 \\
\hline 9 & Type of Agric. Production & & \\
\hline
\end{tabular}




\begin{tabular}{llll}
\hline & subsistence & 18 & 12.0 \\
commercial & 18 & 12.0 \\
both & 114 & 76.0 \\
Income (Naira) & & \\
10 & 55 & 36.7 \\
$20600-205999$ & 37 & 24.7 \\
$402000-597999$ & 15 & 10.0 \\
$598000-793999$ & 23 & 15.3 \\
& 15 & 10.0 \\
\hline
\end{tabular}

Table 2: Distribution of respondent based on transportation

\begin{tabular}{|c|c|c|}
\hline & Frequency & Percentage \\
\hline \multicolumn{3}{|l|}{ (1)Where they sell their produce } \\
\hline Farm gate & 88 & 58.65 \\
\hline Retail & 62 & 41.35 \\
\hline \multicolumn{3}{|l|}{ (2) Cost of transporting produce(Naira) } \\
\hline$<15,000$ & 39 & 26.0 \\
\hline $15,0001-30,00001$ & 26 & 17.3 \\
\hline $30,002-45,002$ & 23 & 15.3 \\
\hline $45,003-60,003$ & 17 & 11.3 \\
\hline $60,004-75,004$ & 9 & 6.0 \\
\hline $75,005-90,005$ & 12 & 8.0 \\
\hline $90,006-105,006$ & 8 & 5.3 \\
\hline $105.007-120,007$ & 6 & 4.0 \\
\hline $120,008-135,000$ & 6 & 4.0 \\
\hline$>135,009$ & 4 & 2.6 \\
\hline \multicolumn{3}{|l|}{ (3) Perception of cost of transportation } \\
\hline High & 105 & 70.0 \\
\hline Moderate & 31 & 20.5 \\
\hline Low & 14 & 9.5 \\
\hline \multicolumn{3}{|l|}{ (4)Constraints on transportation facilities } \\
\hline \multirow{3}{*}{ (Distance and seasonality) } & 71 & 47 \\
\hline & 67 & 44.7 \\
\hline & 12 & 8.3 \\
\hline \multicolumn{3}{|l|}{ (5)Severity of constraints } \\
\hline Very severe & 88 & 58 \\
\hline Severe & 50 & 37 \\
\hline Not severe & 12 & 5 \\
\hline \multicolumn{3}{|l|}{ (6)Coping strategies } \\
\hline Distance to market & 49 & 32.7 \\
\hline Road network & 47 & 20.0 \\
\hline Road seasonality & 48 & 20.6 \\
\hline Cost of transportation & 40 & 26.7 \\
\hline \multicolumn{3}{|l|}{ (7)Availability of agric. Sevices/facilities } \\
\hline Available & 32 & 21.4 \\
\hline Not available & 118 & 78.6 \\
\hline \multicolumn{3}{|l|}{ (8)Accessibility of Agric. Sevices/facilities } \\
\hline Accessible & 53 & 35.3 \\
\hline Not accessible & 97 & 64.7 \\
\hline \multicolumn{3}{|l|}{ (9)Extent transportation serves as barrier to } \\
\hline Agricultural development. & & \\
\hline Very great & 54 & 35.9 \\
\hline Great & 48 & 32.6 \\
\hline
\end{tabular}




\begin{tabular}{lcc}
\hline Low & 23 & 15.4 \\
Not barrier no extent & 25 & 16.1 \\
(10)Opinion on transport facilities and Agricultural & & \\
development. & 99 & 66.1 \\
Strongly agree & 54 & 33.9 \\
Agree & 54 & \\
\hline
\end{tabular}

Note: constraints include; distance to market, road seasonality, road network, cost of transportation number of vehicle, plying the road and type of commodity.

Table 3 Result of Kruskal-Wallis ranking

\begin{tabular}{|c|c|c|}
\hline & Mean & Ranking \\
\hline Transport type: Head porterage & 1128.50 & $2^{\text {nd }}$ \\
\hline Wheel barrow & 822.50 & $5^{\text {th }}$ \\
\hline Motor vehicle & 786.50 & $6^{\text {th }}$ \\
\hline Lorry/truck & 786.50 & $6^{\text {th }}$ \\
\hline Buses & 786.50 & $6^{\text {th }}$ \\
\hline Mini-van & 750 & $9^{\text {th }}$ \\
\hline Pick-up & 1146.50 & $1^{\text {st }}$ \\
\hline Trailer & 1044.50 & $4^{\text {th }}$ \\
\hline Motorcycle & 1092.50 & $3^{\text {rd }}$ \\
\hline \multicolumn{3}{|l|}{ Constraints faced: } \\
\hline Distance of farm to market & 320.48 & $5^{\text {th }}$ \\
\hline Road seasonality & 589.66 & $1^{\text {st }}$ \\
\hline Road network & 477.85 & $4^{\text {th }}$ \\
\hline Cost of transportation & 536.46 & $2^{\text {nd }}$ \\
\hline No of vehicle plying the road & 501.50 & $3^{\text {rd }}$ \\
\hline Type of commodity & 277.05 & $6^{\text {th }}$ \\
\hline \multicolumn{3}{|l|}{ Effect of agricultural facilities on agric. } \\
\hline Development: Agric. extension agent & 444.85 & $7^{\text {th }}$ \\
\hline Agric. product market & 546.13 & $2^{\text {nd }}$ \\
\hline Agric. credit & 462.28 & $5^{\text {th }}$ \\
\hline Hired labour & 455.43 & $6^{\text {th }}$ \\
\hline Agro-chemical & 491.40 & $3^{\text {rd }}$ \\
\hline Improved seeds & 470.03 & $4^{\text {th }}$ \\
\hline Farming input & 806.39 & $1^{\text {st }}$ \\
\hline
\end{tabular}

Table 4 Result of the Pearson on product moment correlation

\begin{tabular}{llll}
\hline Independent variable & Significance (2tailed)(p) & Pearson (r) & Decision \\
\hline Age & 0.930 & -0.007 & Not significant \\
Gender & 0.123 & -0.127 & Not significant \\
Marital status & 0.444 & -0.063 & Not significant \\
Education & 0.061 & 0.155 & Not significant \\
Farming status & 0.667 & 0.035 & Not significant \\
Household size & 0.342 & -0.78 & Not significant \\
Farming experience & 0.848 & -0.016 & Not significant \\
Farm size & 0.668 & -0.668 & Not significant \\
Income & 0.564 & -0.048 & Not significant \\
\hline
\end{tabular}

$* *$ correlation is significant at the 0.01 level ( 2 tailed $)$

$*$ Correlation is significant at the 0.05 level ( 2 tailed) 
An Appraisal of Transportation Facilities Effects on Agricultural..

Akangbe et al.

Table 5 Result of Kruskal-walli one-way analysis of variance (ANOVA) ranking of constraints to efficient transportation in the study area

\begin{tabular}{|l|l|l|l|l|l|l|}
\hline District & Constraints & $\begin{array}{l}\text { Road } \\
\text { seasonality }\end{array}$ & $\begin{array}{l}\text { Road } \\
\text { network }\end{array}$ & Cost & $\begin{array}{l}\text { No of } \\
\text { vehicle }\end{array}$ & $\begin{array}{l}\text { Type of } \\
\text { commodity }\end{array}$ \\
\hline Ejidongari & 79.37 & 61.53 & $96.50^{* *}$ & 90.22 & 87.63 & $102.28^{* *}$ \\
\hline Lanwa & $79.37^{*}$ & 57.70 & $75.97^{* *}$ & 58.72 & 50.77 & 47.97 \\
\hline Oloru & $81.78^{* *}$ & 65.65 & 72.43 & $95.48^{* *}$ & 74.82 & 80.63 \\
\hline Megida & 69.70 & $113.48^{*}$ & 74.23 & 73.70 & $84.12^{* *}$ & 74.57 \\
\hline Malete & 67.28 & $79.13^{*}$ & 67.23 & 59.38 & 65.52 & 77.83 \\
\hline $\mathrm{X}^{2}$ & 8.528 & 45.889 & 6.488 & 28.080 & 27.372 & 27.011 \\
\hline
\end{tabular}

Note: ${ }^{* *}=$ highest and ${ }^{*}=$ second highest

Data analysis on table 5 shows the most prevalent constraint in each district. 